\title{
Endogenous Blockade of 1,25-Dihydroxyvitamin D-Receptor Binding in New World Primate Cells
}

Mercedes A. Gacad and John S. Adams

Division of Endocrinology and Metabolism, Mineral Metabolism Laboratory, Cedars-Sinai Medical Center, University of California at Los Angeles School of Medicine, Los Angeles, California 90048

\begin{abstract}
When assessed by 1,25-dihydroxyvitamin $\mathrm{D}_{3}\left(1,25(\mathrm{OH})_{2}-\mathrm{D}_{3}\right)-$ receptor (VDR) binding analysis or $1,25(\mathrm{OH})_{2}-\mathrm{D}_{3}-\mathrm{VDR}-\mathrm{di}-$ rected bioresponsiveness, cultured cells from some New World primates (platyrrhines) demonstrate a variable decrement in VDR when compared with Old World primate (catarrhine) cells. To study this difference in VDR expression among primates, we performed immunoblot analysis of the VDR in cultured dermal fibroblasts from platyrrhines in the genera Pithecia and Aotus and from catarrhines in the genus Presbytis; although a platyrrhine, the owl monkey (Aotus) expresses a VDR of the catarrhine (wild type) phenotype. Despite a 10-fold difference in the content of VDR by ligand binding analysis among cells from the three prototypic primate genera, there was a $\leq 10 \%$ difference in the steady-state level of 50-kD VDR detected by immunoblot analysis of cellular extracts. We investigated this apparent discrepancy in the content of VDR in immunoblots and ligand binding analyses by mixing VDR-containing nuclear extracts of equivalent protein concentration from the various primates. Coincubation of Pithecia and Aotus fibroblast extracts with Presbytis extract diminished specific $1,25(\mathrm{OH})_{2}-\mathrm{D}_{3}$ binding in the mix by $90 \%$ and $95 \%$, respectively. Similar results were obtained by mixing nuclear extracts of the owl monkey cell line, OMK, and the vitamin D resistant marmoset B-lymphoblast cell line $\mathrm{B95-8}$. A wild type $1,25(\mathrm{OH})_{2}$ $\mathrm{D}_{3}$-binding profile was restored in mixtures after trypsin or heat treatment of the B95-8 extract. These data indicate that some New World primate cells contain a soluble protein that prevents intracellular $1,25(\mathrm{OH})_{2}-\mathrm{D}_{3}-\mathrm{VDR}$ binding. It is possible that the quantitative differences in the expression of this protein are responsible for $1,25(\mathrm{OH})_{2}-\mathrm{D}_{3}$ and other steroid hormone resistant states of variable severity in New World primates. (J. Clin. Invest. 1991.87:996-1001.) Key words: catarrhini • platyrrhini • vitamin D • steroid • fibroblasts
\end{abstract}

\section{Introduction}

The vitamin $D$ endocrine system in many genera of New World primates (platyrrhini) is characterized by a compen-

This work was presented in part before the Western Society for Clinical Investigation, Carmel, California, 7 February 1990.

Address reprint requests to Dr. John S. Adams, B-131, Cedars-Sinai Medical Center, 8700 Beverly Boulevard, Los Angeles, CA 90048.

Received for publication 10 August 1990 and in revised form 18 October 1990.

J. Clin. Invest.

(C) The American Society for Clinical Investigation, Inc. 0021-9738/91/03/0996/06 \$2.00

Volume 87, March 1991, 996-1001 sated form of target organ resistance to the active metabolite of vitamin $\mathrm{D}, 1,25$-dihydroxyvitamin $\mathrm{D}_{3}\left(1,25(\mathrm{OH})_{2}-\mathrm{D}_{3}\right)(1-5)$. When compared with Old World primates (catarrhini), the platyrrhine phenotype is typified by: $(a)$ high circulating concentrations of $1,25(\mathrm{OH})_{2}$-D in the absence of hyperparathyroidism (6); (b) the development of vitamin D-deficient rickets and osteomalacia in some captive platyrrhine species when environmental sunlight exposure is limited $(2,5) ;(c)$ a decrease in the cellular content of high affinity receptor for $1,25(\mathrm{OH})_{2}-\mathrm{D}_{3}$ $(\mathrm{VDR})^{1}$ demonstrable by radiolabeled ligand binding analyses $(2,4,7,8)$; and $(d)$ a decrease in cellular indices of $1,25(\mathrm{OH})_{2-}$ $\mathrm{D}_{3}$-VDR-directed bioaction without an apparent alteration in the nuclear localization and binding of the VDR-hormone complex (2). Similar observations have been made in platyrrhini for other steroid hormones including glucocorticoids, sex steroids, and mineralocorticoids (9). The phenotypic expression of resistance to $1,25(\mathrm{OH})_{2}-\mathrm{D}_{3}$ (as well as other steroid hormones) in various genera of platyrrhini appears to be heterogeneous $(8,9)$. Platyrrhines in the family Callitricidae and some in the family Cebidae exhibit a marked decrement in the cellular content of bioeffective VDR and have a several-fold increase in the serum concentration of $1,25(\mathrm{OH})_{2}-\mathrm{D}(5,8$; Fig. 1). On the other hand, nocturnal cebids in the genus Aotus (night monkey or owl monkey) have a cellular receptor phenotype and serum levels of $1,25(\mathrm{OH})_{2}-\mathrm{D}$ that closely approximate those found in catarrhini, including Homo sapiens (8; Fig. 1). The reason for quantitative differences in the cellular content of functional VDR among New World primate genera is not known. In this report we demonstrate by immunoblot analysis using a monoclonal antibody developed against the VDR (10) quantitative and qualitative similarity of the VDR extracted from catarrhine and platyrrhine cells. In addition, we describe the presence of a factor extracted from cultured platyrrhine cells that disallows $1,25(\mathrm{OH})_{2}-\mathrm{D}_{3}$ binding to VDR extracted from cells derived from catarrhine hosts, Aotus trivergatus, and bovine thymus gland.

\section{Methods}

Primates. Blood and 4-mm transdermal biopsies were obtained under sterile conditions from tranquilized primates in residence at the Los Angeles Zoo. Both procedures were performed during time allotted for annual tuberculosis skin testing and general examination. None of the primates were clinically ill at the time biological material was obtained. Fig. 1 categorizes the donors according to primate infraorder and genus. Platyrrhines were fed $\mathrm{Zu}$-Preem diet containing 8,800 IU vita$\min D_{3} / k g$ (Hills Pet Products, Topeka, KS) supplemented with vitamin D-free yogurt (Johnston's Foods, Glendale, CA). Catarrhines were fed chow (Ralston-Purina Co., Richmond, IN) containing 6,000 IU vitamin $D_{3} / \mathrm{kg}$. Platyrrhines were housed indoors 9 mo of the yr; supple-

1. Abbreviations used in this paper: EBV, Epstein-Barr virus; OMK, owl monkey cell line; VDR, 1,25-dihydroxyvitamin $\mathrm{D}_{3}$ receptor. 


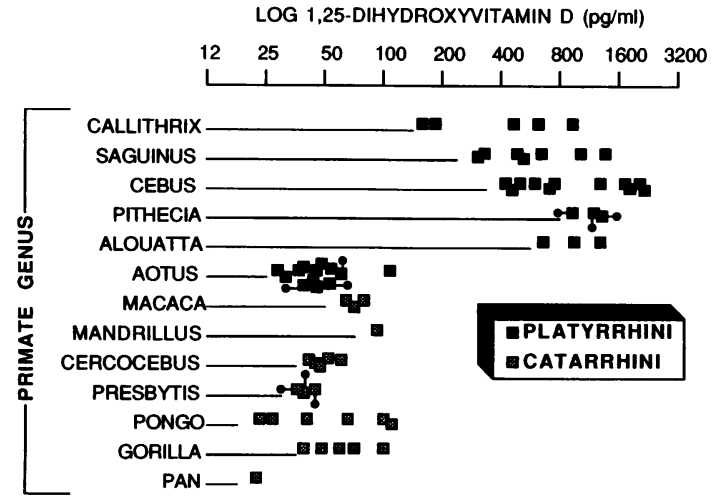

Figure 1. Serum concentrations of 1,25-dihydroxyvitamin D among different genera of New World primates (PLATYRRHINI) and Old World primates (CATARRHINI). Note the log scale. Individual primates, who served as the source of cultured dermal fibroblasts, are indicated by the dots.

mental UV radiation (Vitalite; Westinghouse Electric Corp., Pittsburgh, PA) was available 8-10 h daily. Catarrhines were housed outdoors year-round. Serum $1,25(\mathrm{OH})_{2}$-D concentrations were determined in duplicate by modification of the method of Reinhardt et al. (11); VDR and serum were preincubated for $1 \mathrm{~h}$ at $25^{\circ} \mathrm{C}$ before addition of radiolabeled hormone and incubation for an additional $1 \mathrm{~h}$ at $25^{\circ} \mathrm{C}$. The intra- and interassay coefficient of variation were $8.4 \%$ and $11.6 \%$, respectively. The range of normal for human serum in this assay is $36-144 \mathrm{pmol} /$ liter $(15-60 \mathrm{pg} / \mathrm{ml})$. Serum $1,25(\mathrm{OH})_{2}$-D levels in some of the individual primates shown in Fig. 1 have been previously reported (5).

Cell culture. Full thickness, explant cultures of primate skin were established exactly as previously described (12). Monolayer cultures of dermal fibroblasts were maintained in DMEM (Irvine Scientific, Irvine, CA) supplemented with $10 \%$ fetal bovine serum (FBS; Gemini Bioproducts, Calabasas, CA) $100 \mathrm{U} / \mathrm{ml}$ penicillin, $100 \mu \mathrm{g} / \mathrm{ml}$ streptomycin, and $4 \mathrm{mmol} /$ liter glutamine (all from Irvine Scientific). Fourth to seventh passage fibroblasts were used in all experiments. Two established cell lines from the American Type Culture Collection, Rockville, MD, were used in some experiments. OMK (owl monkey) cells, established from a culture of renal tubular epithelial cells from an adult owl monkey (Aotus trivirgatus) were maintained in modified Eagle's medium (Irvine Scientific) supplemented with $10 \%$ FBS, $100 \mathrm{U} / \mathrm{ml}$ penicillin, $100 \mu \mathrm{g} / \mathrm{ml}$ streptomycin, and $4 \mathrm{mmol} /$ liter glutamine. The B95-8 B-lymphoblastoid cell line was derived from EBV transformation of peripheral blood mononuclear cells of the common marmoset ( $\mathrm{Cal}$ lithrix jacchus). The B95-8 cells were maintained in RPMI 1640 medium (Irvine Scientific) supplemented with $10 \%$ FBS, $100 \mathrm{U} / \mathrm{ml}$ penicillin, $100 \mu \mathrm{g} / \mathrm{ml}$ streptomycin, and $4 \mathrm{mmol} /$ liter glutamine.

$\left[{ }^{3} \mathrm{H}\right] 1,25(\mathrm{OH})_{2}-\mathrm{D}_{3}$ binding analyses. The capacity of $\left[{ }^{3} \mathrm{H}-26,27-\right.$ methyl]1,25-(OH) $)_{2}-\mathrm{D}_{3}(181 \mathrm{Ci} / \mathrm{mmol}$; Amersham Corp., Arlington Heights, IL) to bind with high affinity to the VDR was examined in both intact cells and cellular extracts of VDR. The specific uptake of $\left[{ }^{3} \mathrm{H}\right] 1,25(\mathrm{OH})_{2}-\mathrm{D}_{3}$ by suspensions of intact fibroblasts was determined according to a modification of our previously described method (13, 14). After an 18-h period of preincubation in serum-free medium, confluent fibroblast cultures were harvested and suspended in $200 \mu \mathrm{l}$ Ham's F- 10 medium (pH 7.4) containing $25 \mathrm{mM}$ Hepes, $0.2 \%$ FBS, and varying amounts of $\left[{ }^{3} \mathrm{H}\right] 1,25(\mathrm{OH})_{2}-\mathrm{D}_{3}$ with or without $20 \mathrm{pmol}$ $1,25(\mathrm{OH})_{2}-\mathrm{D}_{3}$ (generously provided by Dr. Milan Uskokovic of Hoffman-LaRoche, Nutley, $\mathrm{NJ}$ ). The suspension was incubated for $1 \mathrm{~h}$ at $37^{\circ} \mathrm{C}$ with continual mixing. Cells were then pelleted by centrifugation and washed twice in Ham's F-10 medium containing 2\% FBS. Receptor-bound $\left[{ }^{3} \mathrm{H}\right] 1,25(\mathrm{OH})_{2}-\mathrm{D}_{3}$ was extracted in $200 \mu \mathrm{l}$ KETD buffer (300 $\mathrm{mM} \mathrm{KCl} 1 \mathrm{mM}$ EDTA, $10 \mathrm{mM}$ Tris- $\mathrm{HCl}$ [pH 7.4], and $5 \mathrm{mM}$ dithiothreitol) supplemented with $10 \mathrm{mM}$ sodium molybdate and $0.5 \%$
Triton X-100. The extract was adjusted to $60 \mathrm{mM} \mathrm{KCl}$ and receptorbound hormone was separated from unbound sterol on DEAE-cellulose filters. Specifically bound hormone was determined by subtracting nonspecific binding (mean of duplicate samples) from total binding (mean of triplicate samples) at each concentration of $\left[{ }^{3} \mathrm{H}\right] 1,25(\mathrm{OH})_{2}$ $D_{3}$ to which the cells were exposed.

In other experiments, the specific interaction of $0.04-1.2 \mathrm{nM}\left[{ }^{3} \mathrm{H}\right]-$ $1,25(\mathrm{OH})_{2}-\mathrm{D}_{3}$ with solubilized VDR in cell extracts was examined. Confluent fibroblast and OMK cell monolayers were harvested by scraping in ice-cold PBS (20 mM Na $2 \mathrm{HPO}_{4}$ [pH 7.2] $150 \mathrm{mM} \mathrm{NaCl}$ ). The cells were pelleted, washed twice in ETD buffer (KETD buffer without $\mathrm{KCl}$ ), and homogenized ( $\mathrm{P}-10$ polytron; Brinkmann Instruments, Inc., Westbury, NY) in the same buffer. Nuclei, with associated VDR, were pelleted at $4,000 \mathrm{~g}$ for $20 \mathrm{~min}$ at $4^{\circ} \mathrm{C}$. The nuclear pellet was washed successively in: ETD buffer; $250 \mathrm{mM} \mathrm{NaCl}$ containing $8 \mathrm{mM}$ EDTA; $10 \mathrm{mM}$ Tris- $\mathrm{HCl}$ (pH 7.4) containing 1\% Triton X-100; and 10 $\mathrm{mM}$ Tris- $\mathrm{HCl}$ (pH 7.4). All of the above buffers contained $5 \mathrm{mM}$ DTT and $1 \mathrm{mM}$ PMSF. The pellet was resuspended in KETD buffer, kept on ice for $30 \mathrm{~min}$, and centrifuged once again at $14,000 \mathrm{~g}$ at $4^{\circ} \mathrm{C}$ for 30 $\mathrm{min}$. The supernatant containing extracted VDR was collected, frozen, and stored at $-70^{\circ} \mathrm{C}$ until used. These nuclear extracts, diluted to the desired volume with KETD buffer, were incubated with $\left[{ }^{3} \mathrm{H}\right]-$ $1,25(\mathrm{OH})_{2}-\mathrm{D}_{3}$ in the presence or absence of $100 \mathrm{nM} 1,25(\mathrm{OH})_{2}-\mathrm{D}_{3}$ for 1 $h$ at $25^{\circ} \mathrm{C}$. Tryptic digestion of B95-8 cell nuclear extracts was achieved by incubation of extracts with trypsin (Sigma Chemical Co., St. Louis, MO) $125 \mu \mathrm{g} / \mathrm{ml}$ for $30 \mathrm{~min}$ at $37^{\circ} \mathrm{C}$, before terminating the enzymatic reaction with trypsin inhibitor (Sigma) $125 \mu \mathrm{g} / \mathrm{ml}$ for $15 \mathrm{~min}$ at $0^{\circ} \mathrm{C}$ before reconstitution with $\mathrm{OMK}$ extract and exposure to radiolabeled hormone. Heat inactivation of B95-8 cell nuclear extract was accomplished by warming extracts to $70^{\circ} \mathrm{C}$ for 30 min before mixing with wild type OMK extract and determination of specific $1,25(\mathrm{OH})_{2}-\mathrm{D}_{3}$ binding. VDR-bound hormone was separated from unbound hormone by dextran-coated charcoal (15) or on DEAE cellulose filters (16). Mixing experiments were performed by assessing specific $1,25(\mathrm{OH})_{2}-\mathrm{D}_{3}$ binding in intergenus mixes of extracts of known protein concentration. Protein content of extracts was determined according to the method of Bradford (17).

Immunoblot detection of VDR. Concentrated nuclear extracts were suspended in electrophoresis buffer containing $0.02 \mathrm{M}$ Tris- $\mathrm{HCl}, 1 \%$ SDS, and $5 \%$ glycine, and heated at $90^{\circ} \mathrm{C}$ for $10 \mathrm{~min}$. The denatured samples were loaded onto $11 \%$ SDS-polyacrylamide gels (Mini-Protein; Bio-Rad Laboratories, Richmond, CA) as described by Laemmli (18) and electrophoresed for $0.5 \mathrm{~h}$ at a fixed voltage of 200 . The gels were transblotted onto nitrocellulose (Bio-Rad, $0.45-\mu \mathrm{m}$ pore size) for $12 \mathrm{~min}$ at $100 \mathrm{~V}$ in transblot buffer containing $25 \mathrm{mM}$ Tris $\mathrm{HCl}, 192$ $\mathrm{mM}$ glycine, $0.1 \%$ SDS, and $20 \%$ methanol. Nitrocellulose membranes were blocked in $1 \%$ Blotto (instant nonfat dry milk; Carnation Co., Los Angeles, CA) in PBS for $1 \mathrm{~h}$ at $25^{\circ} \mathrm{C}$ and then transferred to $0.5 \%$ Blotto in PBS containing $4 \mu \mathrm{g} / \mathrm{ml}$ rat anti-chick VDR monoclonal antibody (9A7, kindly provided by Dr. M. R. Haussler and Dr. J. W. Pike, University of Arizona School of Medicine and Baylor College of Medicine, respectively). After an overnight incubation at $4^{\circ} \mathrm{C}$ with gentle rocking, the membranes were washed three times in Tris-buffered saline (50 $\mathrm{mM}$ Tris- $\mathrm{HCl}$ in $200 \mathrm{mM} \mathrm{NaCl}$; pH 7.4) for $15 \mathrm{~min}$ at $25^{\circ} \mathrm{C}$. The membranes were then transferred to $0.5 \%$ Blotto in PBS containing peroxidase-conjugated goat anti-rat IgG (Cappel Laboratories, Malvern, PA) and incubated for $2 \mathrm{~h}$ at $25^{\circ} \mathrm{C}$. The membranes were once again washed three times in Tris-buffered saline for $15 \mathrm{~min}$ at $25^{\circ} \mathrm{C}$ and then developed with 4-chloro-1-napthol (19).

\section{Results}

Quantitation of VDR. Immunodetection of the VDR in nuclear extracts of cultured dermal fibroblasts of comparable protein content from three different individual primates in three different genera is shown in Fig. 2; included are extracts from 


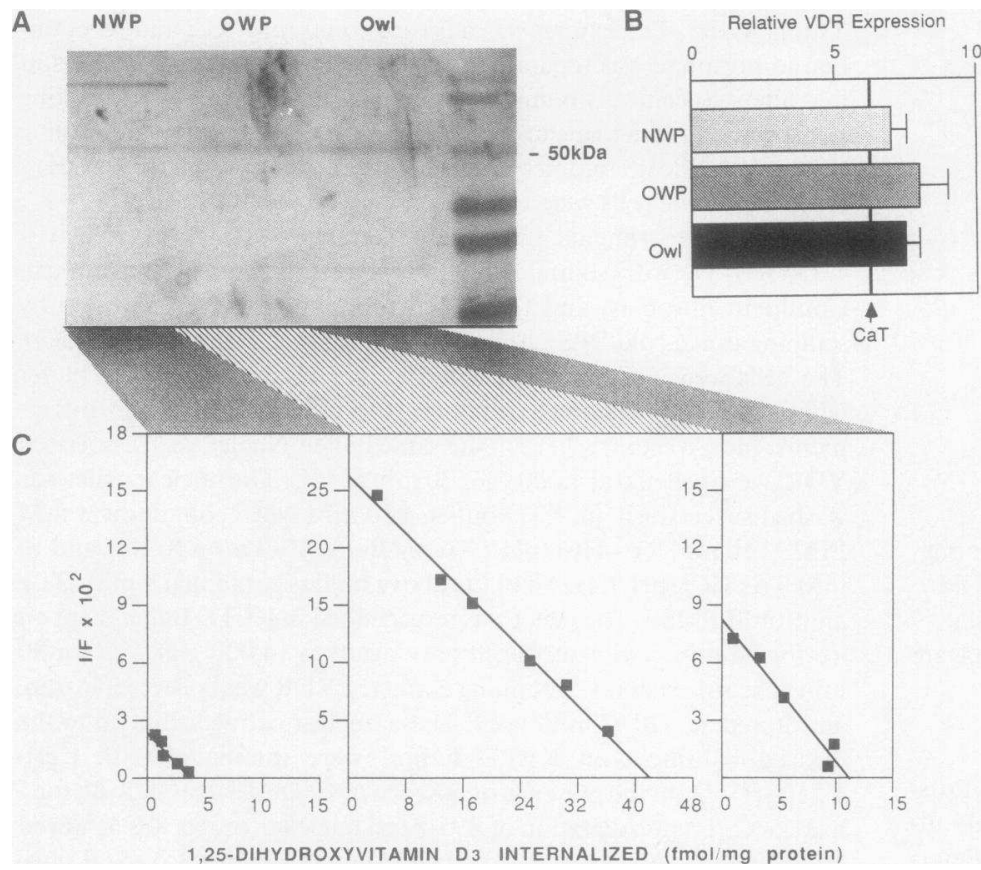

Figure 2. (A) Immunoblot analysis of the vitamin D receptor as extracted from cultured dermal fibroblasts derived from a representative New World primate $(N W P)$, Pithecia pithecia, Old World primate (OWP), Presbytis cristatus, and an owl monkey $(O w)$, a New World primate species Aotus trivergatus. $100 \mu \mathrm{g}$ of protein extract was added to each lane. A molecular weight standard is shown in the far right lane. Immunoreactive species of higher molecular weight are not related to the VDR. (B) Densitometric quantitation of a $50-\mathrm{kD}$ immunoreactive protein extracted from fibroblasts cultured from three different primates in each of the prototypic categories. Each value is standardized against the densitometric value obtained for the 50-kD protein in nuclear extracts of calf thymus $(\mathrm{CaT})$ of equivalent protein concentration run on the same Western blot. Values are expressed as the mean \pm standard error. $(C)$ Scatchard plots of the specific internalization and nuclear binding of $\left[{ }^{3} \mathrm{H}\right] 1,25$ dihydroxyvitamin $\mathrm{D}_{3}$ by fibroblasts derived from the same primate host shown in $A$. The calculated internalization constant $\left(K_{\text {in }}\right)$ for cells from all three primates was essentially identical $(0.04-0.05 \mathrm{nM})$. The $x$ intercept indicates the relative $1,25(\mathrm{OH})_{2}-\mathrm{D}_{3}$ binding capacity of the cells.

an Old World primate (catarrhine) in the genus Presbytis, a New World primate (platyrrhine) in the genus Pithecia, and a New World primate in the genus Aotus. Although Aotus trivergatus or owl monkey is found in the suborder platyrrhini, it possesses the functional VDR phenotype of Old World primates (8). In the case of each extract, a $50-\mathrm{kD}$ protein was identified by the rat anti-chick monoclonal antibody developed against the VDR. Evidence that the $50-\mathrm{kD}$ species detected on Western blots was the VDR was obtained by: $(a)$ coelution of the immunodetectable $50-\mathrm{kD}$ protein with specifically bound $\left[{ }^{3} \mathrm{H}\right] 1,25(\mathrm{OH})_{2}-\mathrm{D}_{3}$ from DEAE anion exchange HPLC $(7.5 \mathrm{~mm} \times 7.5 \mathrm{~cm}$ Protein Pak-DEAE-5PW; Waters Associates, Millipore Corp., Milford, MA) through linear and stepwise gradients of $\mathrm{KCl}(0.05-0.5 \mathrm{M}) ;(b)$ a two to threefold increase in the immunodetectable $50-\mathrm{kD}$ protein in VDR-containing rat osteogenic sarcoma (ROS 17.2) cells after overnight incubation with $50 \mathrm{nM}$ dexamethasone; glucocorticoids are known to enhance specific $1,25(\mathrm{OH})_{2}-\mathrm{D}_{3}$ binding in these cells two to threefold (20); and (c) demonstration that a subclone of this cell line (ROS 24.1), which lacks specific $1,25(\mathrm{OH})_{2}-\mathrm{D}_{3}$ binding capacity (21), possessed no detectable VDR on immunoblot analysis.

In addition to demonstrating identical elution positions on Laemmli gels, the steady-state level of extractable VDR appeared to be quantitatively similar among cells from the three prototypic genera examined (Fig. $2 \mathrm{~A}$ ). This observation was confirmed in densitometric analyses of Western blots of cellular extracts derived from nine different individual primates, three in each of the prototypic categories (Fig. $2 \mathrm{~B}$ ). When compared with VDR in extracts of calf thymus, there was no significant difference in the amount of 50-kD VDR detected among primates in different genera. Despite a quantitative similarity in the cellular concentration of immunodetectable VDR, there was a dramatic difference in the cellular content of VDR when assessed by specific ligand binding analyses (Fig. $2 \mathrm{C}$ ). New World primate fibroblasts exhibited a $90 \%$ reduction in the number of high affinity intracellular binding sites observed in Old World primate cells. New World primate fibroblasts from the owl monkey, however, had a threefold greater $1,25(\mathrm{OH})_{2}-\mathrm{D}_{3}$ binding capacity than that observed in cells cultured from platyrrhines in another genera. An observed VDRhormone binding capacity in owl monkey cells intermediate between that of other platyrrhines and catarrhines is compatible with our previous report (8). The internalization constant of VDR for $1,25(\mathrm{OH})_{2}-\mathrm{D}_{3}$ among cells from various hosts of primates was comparable.

Reconstitution experiments. In an attempt to restore specific hormone binding capacity to extracts of New World primate cells, we mixed Pithecia (resistant) cell extract with an equal amount (on a milligram protein basis) of Presbytis and calf thymus (wild type) cell extract. As depicted in the experiment in Fig. $3 A$, wild type VDR bound 20-60 times more hormone than resistant VDR from the New World primate Pithecia. Mixing equal amounts of the two wild type extracts preserved the wild type phenotype. However, mixing calf thymus extract with resistant extract reduced wild type VDR-hormone binding to $24 \%$, not $50 \%$, of the expected value. The specific binding of $\left[{ }^{3} \mathrm{H}\right] 1,25(\mathrm{OH})_{2}-\mathrm{D}_{3}$ in wild type extract from the Old World primate Presbytis was completely abolished by addition of the extract with the resistant phenotype. Extract with the resistant phenotype had a similar effect on hormone binding to VDR in an extract from fibroblasts cultured from the owl monkey Aotus trivergatus (Fig. 3 B); the owl monkey appears to express a wild type VDR even though this species is a New World primate (8). The effect of mixing a given concentration of wild type extract with increasing dilutions of resistant extract is shown in Fig. 4. Even when the resistant extract constituted as little as $8 \%$ of the protein in the reaction mixture, there was complete inhibition of specific $1,25(\mathrm{OH})_{2}-\mathrm{D}_{3}$ binding in wild type extract from Old World primate fibroblasts. Halfmaximal hormone binding in wild type extracts was not achieved until the protein concentration of the resistant extract was reduced to only $2 \%$ of the protein content of the reaction mixture. 


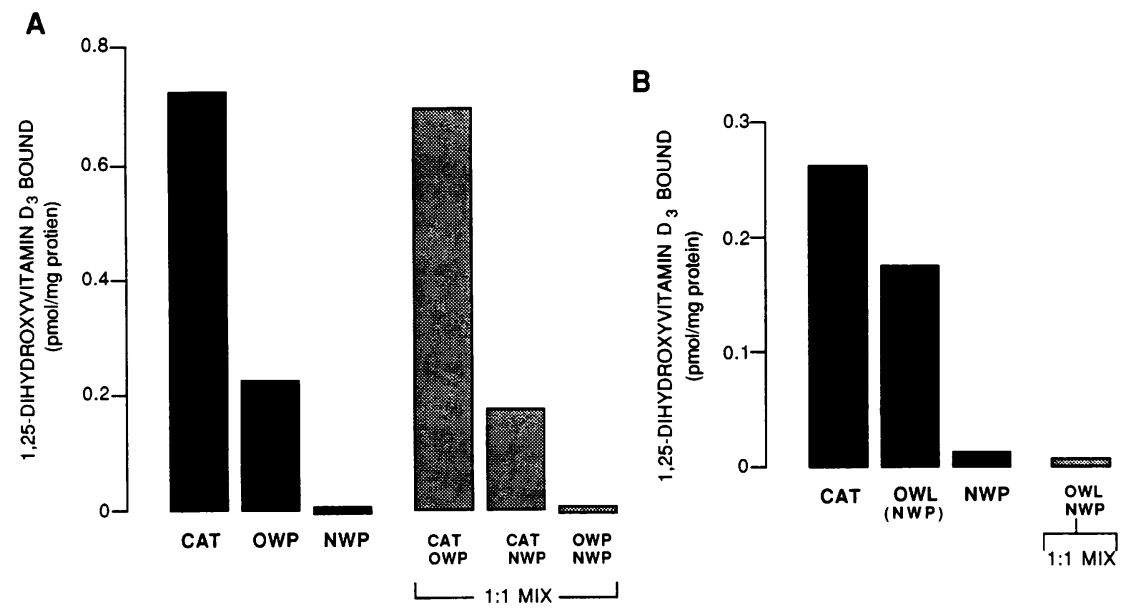

Figure 3. (A) Specific binding of $\left[{ }^{3} \mathrm{H}\right] 1,25$ dihydroxyvitamin $\mathrm{D}_{3}(5 \mathrm{nM})$ in extracts of cultured dermal fibroblasts from a representative Old World primate (OWP; Presbytis cristatus) and New World primate, (NWP; Pithecia pithecia), in extracts of calf thymus (CAT), and in preparations where extracts (of equivalent protein content) were mixed in equal parts. Each value is the mean of three determinations of specific hormone binding. $(B)$ A similar experiment employing a different extract of calf thymus $(C A T)$, fibroblasts from an owl monkey $(O W L)$, and fibroblasts from another New World primate $(N W P)$ in the genus Pithecia. Each value is the mean of duplicate determinations of specific hormone binding.

The capacity of nuclear extract from cells with the resistant phenotype to limit hormone binding to wild type VDR was confirmed in cell lines established from different tissue sources. As shown in Fig. 5, nuclear extracts of B95-8 cells, EBV-transformed B-lymphoblasts from a common marmoset, exhibited minimal high affinity binding of $1,25(\mathrm{OH})_{2}-\mathrm{D}_{3}$ when compared with extracts of calf thymocytes and OMK cells, a cell line of renal tubular epithelial cells derived from the kidney of an adult owl monkey. These data indicate that OMK cells and B95-8 cells are representative of the wild type and vitamin Dresistant phenotype, respectively, expressed by cultured dermal fibroblasts from New World primates with these characteristic phenotypes. As was the case with nuclear extract from Pithecia fibroblasts, B95-8 cells completely inhibited $1,25(\mathrm{OH})_{2}-\mathrm{D}_{3}$ binding to VDR in wild type extracts of OMK cells when the two extracts were mixed in equal proportion before exposure to hormone (Fig. 5). Serial dilution of B95-8 cell nuclear extract gradually restored $1,25(\mathrm{OH})_{2}-\mathrm{D}_{3}$ binding to wild type VDR with the half-maximal inhibitory effect imparted when $\sim 15 \%$ of the reaction mixture consisted of B95-8 cell extract.

The mixing experiments suggested that there existed in nuclear extracts of vitamin D-resistant New World primate cells a soluble factor(s) that prevented the high affinity interaction of

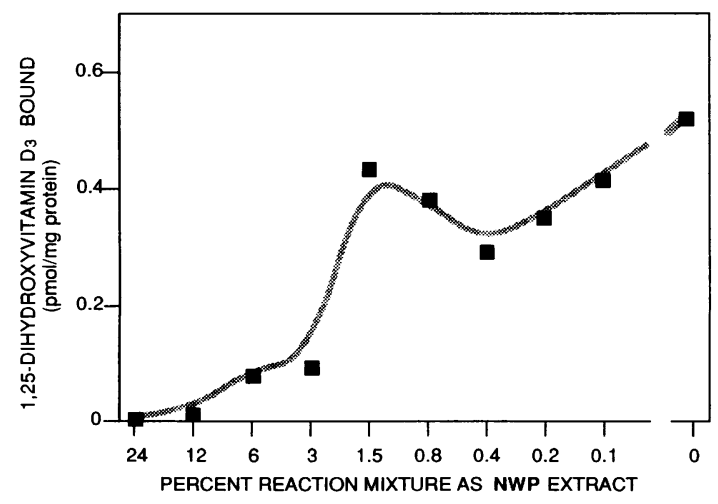

Figure 4. Specific binding of $\left[{ }^{3} \mathrm{H}\right] 1,25$-dihydroxyvitamin $\mathrm{D}_{3}$ in Old World primate (Presbytis cristatus) fibroblast extracts $(100 \mu \mathrm{g} / \mathrm{ml})$ mixed with increasing dilutions of New World primate (NWP; Pithecia pithecia) fibroblast extract of an initial equivalent protein concentration. Each point is the mean of duplicate determinations.
$1,25(\mathrm{OH})_{2}-\mathrm{D}_{3}$ with its cognate receptor. Data indicating the proteinaceous character of this factor are presented in Fig. $5 \mathrm{C}$. Treatment of B95-8 extract with trypsin $(125 \mu \mathrm{g} / \mathrm{ml})$ before mixing with OMK extract and exposure to hormone resulted in complete restoration of wild type binding. Likewise, heating of B95-8 extract to $70^{\circ} \mathrm{C}$ for $30 \mathrm{~min}$ before reconstitution with OMK extract also resulted in a marked increase (sevenfold) in specific $1,25(\mathrm{OH})_{2}-\mathrm{D}_{3}$ binding.

\section{Discussion}

VDR-1,25(OH $)_{2}-\mathrm{D}_{3}$ binding analyses, using intact cells or extracted VDR from platyrrhine hosts (except cells from platyrrhines in the genus Aotus), demonstrate a clear decrease in the cellular concentration of high affinity VDR when compared with catarrhine cells (Fig. 2). There are several potential explanations for this relative decrease in the cellular content of VDR in platyrrhines. The two most obvious explanations are decreased production or increased catabolism of VDR in platyrrhine cells. However, our data employing immunoblot detection of the protein suggest that there is quantitative as well as qualitative similarity in the steady-state levels of the $50-\mathrm{kD}$ VDR species in cellular extracts from all genera of primates tested (Fig. 2). There are, in turn, several possible explanations for the apparent discrepancy in the ligand binding and immunoblot data obtained in platyrrhine cells with the vitamin D-resistant phenotype.

First, it is possible that there is a structural alteration in the ligand binding domain of the receptor that in some way variably diminishes the total number of steroid molecules that can be bound. This possibility is unlikely in that one would expect such a change in the VDR to result in a concomitant change in the affinity of the VDR for $1,25(\mathrm{OH})_{2}-\mathrm{D}_{3}$. Previous reports from us $(2,8)$ and other investigators $(4,7)$ indicate there is little or no change in the affinity of platyrrhine VDR for the vitamin $\mathrm{D}$ hormone. Another possible but improbable cause for diminished $1,25(\mathrm{OH})_{2}-\mathrm{D}_{3}$ binding in New World primate cells without a change in steady-state VDR levels could be accelerated catabolism of $\left[{ }^{3} \mathrm{H}\right] 1,25(\mathrm{OH})_{2}-\mathrm{D}_{3}$ in platyrrhine cells (22). This is unlikely considering that the major intracellular catabolic pathway for $1,25(\mathrm{OH})_{2}-\mathrm{D}_{3}$ is the 24-hydroxylase and the activity of this enzymatic reaction is markedly decreased, 

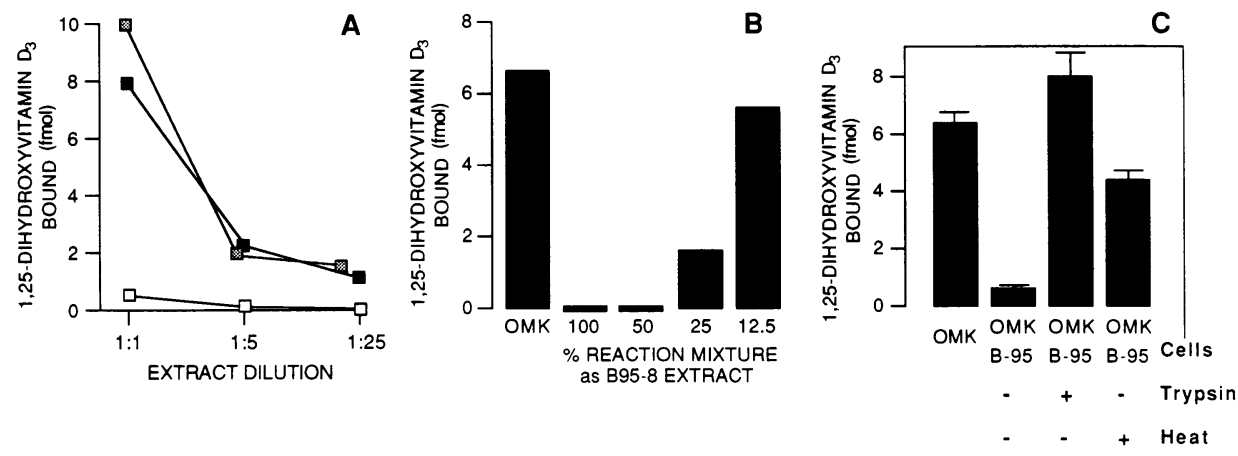

Figure 5. (A) Specific binding of $1 \mathrm{nM}$ $\left[{ }^{3} \mathrm{H}\right] 1,25(\mathrm{OH})_{2}-\mathrm{D}_{3}$ by dilutions of nuclear extract from calf thymocytes (hatched boxes), the owl monkey kidney cell line (OMK; solid boxes), and the marmoset lymphoblast cell line (B95-8; open boxes). The protein concentration of the undiluted sample was $100 \mu \mathrm{g} / \mathrm{ml}$ in each case. Each point is the mean of duplicate determinations of specific hormone binding. $(B)$ Ability of serial dilutions of the B95-8 cell nuclear extract to inhibit hormone ( $1 \mathrm{nM}$ ) binding to vitamin D receptor (VDR) in the OMK cell nuclear extract. The total protein concentration of each reaction mixture was $50 \mu \mathrm{g} / \mathrm{ml}$. Each value is the mean of duplicate determinations of specific hormone binding. $(C)$ Specific binding of $1 \mathrm{nM}\left[{ }^{3} \mathrm{H}\right] 1,25(\mathrm{OH})_{2}-\mathrm{D}_{3}$ in mixtures of nuclear extract from OMK and B95-8 cells before and after treatment of the B95-8 cell extract with trypsin $(125 \mu \mathrm{g} / \mathrm{ml})$ or heat $\left(70^{\circ} \mathrm{C}\right)$ for $30 \mathrm{~min}$. The protein concentration of each of the individual cell extracts was $50 \mu \mathrm{g} / \mathrm{ml}$; mixtures contained $100 \mu \mathrm{g} / \mathrm{ml}$ total protein. Each value is the mean \pm standard deviation of triplicate determinations.

not increased, in New World primate cells (8). Furthermore, diminished VDR-hormone binding activity persists in nuclear extracts of platyrrhine cells (Fig. 3) that should be devoid of mitochondrial vitamin D-24-hydroxylase activity.

A third possible explanation, compatible with the results of our mixing experiments (see Figs. 3 and 4), is that platyrrhine cell nuclear extracts contain a soluble factor that prevents exogenous $1,25(\mathrm{OH})_{2}-\mathrm{D}_{3}$ from interacting with the hormone-binding domain of the VDR. The existence of such a factor is most compatible with the results represented here. Since this factor does not bind $1,25(\mathrm{OH})_{2}-\mathrm{D}_{3}$, it should not quantitatively affect the affinity of the VDR for $1,25(\mathrm{OH})_{2}-\mathrm{D}_{3}$ or the cellular concentration of immunodetectable, 50-kD VDR under denaturing gel conditions. Such a factor was also documented to be present in nuclear extracts of the B95-8 B-lymphoblast cell line derived from EBV-transformation of marmoset (Callithrix jacchus) peripheral blood cells (Fig. 5), indicating that this factor is not specific for a particular platyrrhine species, a specific tissue, or primary cell culture. The factor is water soluble, and a substantial amount of it is colocalized, along with VDR, to the nucleus under "low salt" conditions. The factor along with VDR can be coextracted from the nucleus in "high salt" buffer. Although this factor does not appear to coelute with the VDR from DEAE cellulose HPLC through a gradient of $\mathrm{KCl}(0.05-$ $0.5 \mathrm{M}$ ), it apparently does coelute with the VDR from isolated nuclei through a stepwise gradient of $\mathrm{KCl}$ (2). Treatment of B95-8 cell nuclear extract with a concentration of trypsin known to effectively digest the VDR (23) resulted in reexpression of the wild type binding phenotype in mixtures of OMK and B95-8 extract. Additional evidence supporting the proteinaceous nature of the factor in B95-8 cell nuclear extract was derived from OMK:B95-8 reconstitution experiments that demonstrated reexpression of the wild type phenotype after heat inactivation of the factor in B95-8 extract. Possible candidates for this factor include a kinase inhibitor or a phosphatase that disallows phosphorylation or dephosphorylates residues in the ligand binding domain of the VDR; the VDR is known to be subject to rapid, $1,25(\mathrm{OH})_{2}-\mathrm{D}_{3}$-dependent phosphorylation $(24,25)$, a casein-kinase II-mediated event that may be critical in conversion of the VDR to an "active" state (26). Another potential candidate for this factor is one of the heat shock proteins. hsp-90 and hsp-70 are both known to bind to the ligand binding domain of steroid receptors $(27,28)$. However, unlike other steroid hormone receptors $(27,29-36)$, there is no evidence to suggest that the VDR is associated with heat shock proteins either in vivo or in vitro (37).

A fourth potential explanation for the observed discrepancy in the ligand binding and immunoblot results obtained in platyrrhine cells is that there exists in platyrrhine cells another factor that competes with endogenous VDR for $1,25(\mathrm{OH})_{2}-\mathrm{D}_{3}$ binding. This explanation is compatible with the mixing experiments described in Figs. 3, 4, and 5, which demonstrate that platyrrhine cell extracts contain a soluble factor that inhibits ligand binding to catarrhine and Aotus VDR and that this factor is relatively plentiful. Such a protein would not be expected to be bound by antireceptor antibody and, therefore, would not be detected by immunoblot analysis. Compared with the VDR, this protein would also have to exhibit higher capacity but much lower affinity for $1,25(\mathrm{OH})_{2}-\mathrm{D}_{3}$ as there is little or no specific binding of $1,25(\mathrm{OH})_{2}-\mathrm{D}_{3}$ to VDR from platyrrhine cells at radioligand concentrations $\leq 1 \mathrm{nM}$. A second binding moiety with such characteristics (high capacity and low affinity) has not yet been detected in platyrrhine cell nuclear extracts but investigation of the presence of such a factor in other cellular compartments is underway.

The VDR, receptors for other steroid hormones, as well as the intracellular receptor proteins for thyroid hormone and retinoic acid likely evolved from a common ancestral gene by reduplication (38). These genetic events are relatively ancient when compared to the separation of the South American and African continental land masses (50-60 million years ago) and the independent evolution of platyrrhines and catarrhines. Therefore, if the platyrrhine phenotype of multiple steroid hormone resistance were due to mutational events at the level of the receptor proteins, one would have to postulate the occurrence of concurrent mutations in the ligand binding domain of each of the receptor genes. A far more plausible explanation would be genetic alteration of a single protein, like hsp-90 or a kinase, which has the potential to interact with the ligand binding domain of each and every one of these receptor proteins. Moreover, quantitative differences in the level of expression of this protein could give rise to the phenotypic heterogeneity in steroid hormone-receptor interactions observed among different genera of primates (8). 


\section{Acknowledgments}

The authors would like to thank Donald McDonnell, Ph.D., and Shraga Shany, Ph.D., for their helpful advice, Micheal Rothman for his photographic expertise, and Ms. Millie Barron for preparation of the manuscript.

This work was supported by grant AR-37399 from the National Institutes of Health.

\section{References}

1. Shinki, T., Y. Shiina, N. Takahashi, Y. Tamoika, H. Koizumi, and T. Suda. 1983. Extremely high circulating levels of 1,25-dihydroxyvitamin $D_{3}$ in the marmoset, a New World monkey. Biochem. Biophys. Res. Commun. 114:452-457.

2. Adams, J. S., M. A. Gacad, A. J. Baker, G. Keuhn, and R. K. Rude. 1985. Diminished internalization and action of 1,25-dihydroxyvitamin $D_{3}$ in dermal fibroblasts cultured from New World primates. Endocrinology. 116:2523-2527.

3. Liberman, U. A., D. deGrange, and S. J. Marx. 1985. Low affinity of the receptor for $1 \alpha, 25$-dihydroxyvitamin $\mathrm{D}_{3}$ in the marmoset, a New World monkey. FEBS (Fed. Eur. Biochem. Soc.) Lett. 182:385-389.

4. Takahashi, N., S. Suda, T. Shinki, N. Horiuchi, Y. Shiina, Y. Tanioka, H. Koizumi, and T. Suda. 1985. The mechanism of end-organ resistance to 1,25-dihydroxycholecalciferol in the common marmoset. Biochem. J. 227:555-563.

5. Adams, J. S., M. A. Gacad, A. J. Baker, B. Gonzales, and R. K. Rude. 1985. Serum concentrations of 1,25-dihydroxyvitamin $\mathrm{D}_{3}$ in Platyrrhini and Catarrhini: a phylogenetic appraisal. Am. J. Primatol. 9:219-224.

6. Adams, J. S., M. A. Gacad, R. K. Rude, M. Deseran, D. B. Endres, and L. E. Mallette. 1987. Immunoreactive parathyroid hormone levels in Platyrrhini and Catarrhini: a comparative analysis with three different assays. Am. J. Primatol. 13:425-433.

7. Kelly, M. A., D. J. Mangelsdorf, C. A. Donaldson, J. W. Pike, and N. H. Bell. 1986. Are all New World primates resistant to 1,25-dihydroxyvitamin D? In 68th Annual Meeting of the Endocrine Society, Anaheim, CA. p. 55. (Abstr.)

8. Adams, J. S., and M. A. Gacad. 1988. Phenotypic diversity of the cellular 1,25-dihydroxyvitamin $D_{3}$-receptor interaction among different genera of New World primates. J. Clin. Endocrinol. \& Metab. 66:224-229.

9. Brandon, D. D., A. J. Markwick, G. P. Chrousos, and D. L. Loriaux. 1989. Glucocorticoid resistance in humans and nonhuman primates. Cancer Res. 49(Suppl.):2203-2213.

10. Pike, J. W., S. L. Marion, C. A. Donaldson, and M. R. Haussler. 1983. Serum and monoclonal antibodies against the chick intestinal receptor for $1,25-$ dihydroxyvitamin $\mathrm{D}_{3}$. J. Biol. Chem. 258:1289-1296.

11. Reinhardt, T. A., R. L. Horst, J. W. Orf, and B. W. Hollis. 1984. A microassay for 1,25-dihydroxyvitamin D not requiring high performance liquid chromatography: application to clinical studies. J. Clin. Endocrinol. \& Metab. 58:91-98.

12. Martin, G. M. 1973. Tissue Culture Methods and Application. Academic Press, New York. P. 39.

13. Adams, J. S. 1984. Specific internalization of 1,25-dihydroxyvitamin $D_{3}$ by cultured intestinal epithelial cells. J. Steroid Biochem. 20:857-862.

14. Adams, J. S., M. A. Gacad, and F. R. Singer. 1984. Specific internalization and action of 1,25-dihydroxyvitamin $\mathrm{D}_{3}$ in cultured dermal fibroblasts from patients with X-linked hypophosphatemia. J. Clin. Endocrinol. \& Metab. 59:556560.

15. Pike, J. W. 1984. Monoclonal antibodies to chick intestinal receptors for 1,25-dihydroxyvitamin $\mathrm{D}_{3}$ : Interaction and effects of binding on receptor function. J. Biol. Chem. 259:1167-1173.

16. Santi, D. V., C. H. Selbey, E. R. Perriard, G. Tomkins, and J. D. Baxter. 1973. A filter assay for steroid hormone receptors. Biochemistry. 12:235-243.

17. Bradford, M. 1976. A rapid and sensitive method for the quantitation of microgram quantities of protein utilizing the principle of protein-dye binding. Anal. Biochem. 72:248-254.
18. Laemmli, U. K. 1970. Cleavage of structural proteins during assembly of the head of bacteriophage T-4. Nature (Lond.). 227:680-685.

19. Dame, M. C., E. A. Pierce, and H. F. DeLuca. 1985. Identification of the porcine intestinal 1,25-dihydroxyvitamin $D_{3}$ receptor on sodium sulfate/polyacrylamide gels by renaturation and immunoblotting. Proc. Natl. Acad. Sci. USA 82:7825-7829.

20. Manolagas, S. C., J. Abare, and L. J. Deftos. 1984. Glucocorticoids increase the $1,25(\mathrm{OH})_{2}-\mathrm{D}_{3}$ receptor concentration in rat osteogenic cells. Calif. Tissue Int. 36:153-157.

21. Majeska, R. J., and G. A. Rodan. 1982. The effect of $1,25(\mathrm{OH})_{2}-\mathrm{D}_{3}$ on alkaline phosphatase in osteoblastic osteosarcoma cells. J. Biol. Chem. 257:33623365.

22. Reinhardt, T. A., R. L. Horst, G. W. Engstrom, and K. B. Atkins. 1988. Ketoconazole potentiates $1,25(\mathrm{OH})_{2}-\mathrm{D}_{3}$-directed upregulation of $1,25(\mathrm{OH})_{2}-\mathrm{D}_{3}$ receptors in rat intestine and bone. In Vitamin D: Molecular, Cellular, and Clinical Endocrinology. A. W. Norman, K. Schaefer, H. C. Grigoleit, and D. V. Herrath, editors. Walter de Gruyter \& Co., Berlin. 233-234.

23. Allegretto, E. A., and J. W. Pike. 1985. Trypsin-cleavage of chick 1,25-dihydroxyvitamin $\mathrm{D}_{3}$ receptors. J. Biol. Chem. 260:19128-10145.

24. Pike, J. W., and N. M. Sleator. 1985. Hormone-dependent phosphorylation of the 1,25-dihydroxyvitamin $D_{3}$ receptor in mouse fibroblasts. Biochem Biophys. Res. Commun. 131:378-385.

25. Brown, T. A., and H. F. DeLuca. 1990. Phosphorylation of the 1,25-dihydroxyvitamin $D_{3}$ receptor: a primary event in 1,25-dihydroxyvitamin $D_{3}$ action. J. Biol. Chem. 265:10025-10027.

26. Jurutka, P. W., C. M. Terpening, and M. R. Haussler. 1990. The vitamin $D$ receptor in rat osteoblast-like cells is phosphorylated in response to $1,25(\mathrm{OH})_{2-}$ $\mathrm{D}_{3}$ in vivo and by casein kinase II, in vitro. J. Bone Miner. Res. 5:S200. (Abstr.)

27. Linquist, S., and E. A. Craig. 1988. The heat-shock proteins. Annu. Rev. Genet. 22:631-677.

28. Carson-Jurica, M. A., W. T. Schraeder, and B. W. O'Malley. 1990. Steroid receptor family: structure and function. Endocr. Rev. 11:201-220.

29. Housley, P. R., E. R. Sanchez, H. M. Westphal, M. Beato, and W. B. Pratt. 1985. The molybdate-stabilized L-cell glucocorticoid receptor isolated by affinity chromatography or with a monoclonal antibody is associated with a $90-92 \mathrm{kDa}$ non-steroid-binding phosphoprotein. J. Biol. Chem. 260:13810-13817.

30. Mendel, D. B., J. E. Bodwell, B. Gametchu, R. W. Harrison, and A Munck. 1986. Molybdate-stabilized nonactivated glucocorticoid-receptor complexes contain a $90-\mathrm{kDa}$ non-steroid-binding phosphoprotein that is lost on activation. J. Biol. Chem. 261:3758-3763.

31. Sanchez, E. R., D. O. Toft, M. J. Schlesinger, and W. B. Pratt. 1985. Evidence that the 90-kDa phosphoprotein associated with untransformed L-cel glucocorticoid receptor is a murine heat-shock protein. J. Biol. Chem. 260:12398-12401.

32. Catelli, M. G., N. Binart, I. Jung-Testas, J. M. Renoir, E. E. Baulieu, J. R. Feramisco, and W. J. Welch. 1985. The common 90-kd protein component of non-transformed " $8 \mathrm{~S}$ " steroid receptors is a heat shock protein. EMBO (Eur Mol. Biol. Organ.) J. 4:3131-3135.

33. Dennis, M., A.-C. Wikstom, and J.-A. Gustafsson. 1987. The molybdatestabilized nonactivated glucocorticoid receptor contains a dimer of $M_{r} \sim 90,000$ non-hormone-binding protein. J. Biol. Chem. 262:11803-11806.

34. Joab, I., Radanyi, J. M. Renoir, T. Buchou, M. G. Catelli, N. Binart, J. Mester, and E.-E. Baulieu. 1984. Common non-hormone binding component in non-transformed chick oviduct receptors of four steroid hormones. Nature (Lond.). 308:850-853

35. Kost, S. L., D. F. Smith, W. P. Sullivan, W. J. Welch, and D. O. Toft. 1989. Binding of heat shock proteins to the avian progesterone receptor. Mol. Cell. Biol. 9:3829-3838.

36. Redeuilh, G., B. Moncharmont, C. Secco, and E.-E. Baulieu. 1987. Subunit composition of the molybdate-stabilized "8-9S" nontransformed estradiol receptor purified from calf uterus. J. Biol. Chem. 262:6969-6973.

37. Wecksler, W. R., and A. W. Norman. 1980. Biochemical properties of 1,25-dihydroxyvitamin D receptors. Steroid Biochem. 13:977-989.

38. Evans, R. M. 1988. The steroid and thyroid hormone receptor superfamily. Science (Wash. DC). 240:889-895. 